\title{
The Changing Perception of the African Woman towards Patriarchy and Masculinity
}

\author{
Taku Catherine Arrey-Ngang
}

Faculty of Arts, Department of English, University of Buea, Cameroon

\begin{abstract}
Patriarchy is a social structure in which men are the primary holders of power, and are preponderate in roles of local authority, political leadership, economic power and control of property. Several African literary productions focus on the suffering of women in such patriarchal setup with men being very domineering and women oppressed; the man is always at the helm with the woman being the silent observer. In most cases, property and family name are passed down within the male line of inheritance. Basically, men are in charge. This article however exposes the changing awareness of today's African woman from one who is governed to being more in control of her surroundings. Using two African plays: Ola Rotimi's Our Husband Has Gone Mad Again and Anne Tanyi Tang's Eneta vs Elimo, we argue that women have evolved from being disenfranchised dependents and voiceless recipients to assertive and productive contributors in their families and society. Deconstruction and Nego-feminism are applied here to reveal how women negotiate their way through patriarchy as a means of achieving their goals of empowerment and determination to effect socio-political change.
\end{abstract}

Keywords: Perception, Patriarchy, Masculinity, Chauvinism, Deconstruction, Nego-feminism).

\section{Introduction}

There has existed a significant feminist concern about the study of men and masculinities. The idea has persisted because many thought that a focus on men and masculinities would meddle with the responsiveness from issues about women and women's inequalities, but this hasn't been the case. This concern has led to a noticeable growing interest in the study of masculinities; and there has equally arisen a growing body of literature hypothesizing maleness and its closeness to female qualities. Raewyn W. Connell (1987) thinks that this can be perceived by the emergence of masculinity and men's studies as legitimate areas of scholarly work in the social sciences. They hold that the attention has extended to academic publications on men, with certain journals like the Journal of Men and Masculinities taking the lead. This researcher thinks that broadening the gender perspective to include men and masculinity would help widen and deepen the understanding of power and inequality between men and women, as well as between men and their community.

Madam Ajanaku in Ola Rotimi's Our Husband Has Gone Mad Again and Eneta in Eneta vs Elimo are nonliterate and illiterate characters respectively, who are astonishingly very strong-willed women. They, and several other characters, have proven that women's perception of the world is changing. The woman's place is not just in the kitchen because she too is born with qualities that can be exploited. This work therefore sustains the hypothetical contention articulated in line with the emergence of some assertive and selfimposing African women who are determined to fight patriarchy and masculinity. These women also bear masculine traits by their own rights. The aim is to demonstrate that even though women are considered as the underprivileged, they have always performed important roles in society and more women are challenging patriarchy and taking up more leadership roles in their community.

In this article we employ African feminism with special emphasis on nego-feminism to bring out the female perception of masculinity. We look at how the African woman's view of patriarchy has evolved over the years, and where she places herself in today's society. In her article "Nego-Feminism: Theorizing, Practicing, and Pruning Africa's Way", African feminist writer and scholar, Obioma Nnaemeka (2005) defines the term "Nego-feminism" as "the feminism of negotiation; second, nego-feminism stands for 'no 
ego' feminism and is structured by cultural imperatives and modulated by ever-shifting local and global exigencies". In most African countries, the culture of negotiation and compromise is very noticeable especially when it comes to reaching settlements in family matters. For African women to win challenges, they must negotiate and sometimes compromise enough in order to gain freedoms, especially because it is a matter of give and take. Nnaemeka writes that African feminism works by knowing "when, where, and how to detonate and go around patriarchal land mines". This means that nego-feminism knows how to utilize the culture of negotiation in order to deconstruct patriarchy to the woman's advantage.

\section{Patriarchy and Masculinity in African plays}

Different definitions exist of patriarchy today. Some feminists say it is an unwarranted social system that subordinates, discriminates or is overbearing to women, but bell hooks (2000) affirms that patriarchy is the single most life-threatening social disease assaulting the male body and spirit in the African society, yet most men do not use the word "patriarchy" in their everyday life. She says most men never think about patriarchy - what it means, how it is created and sustained. To hooks,

Patriarchy is a political-social system that insists that males are inherently dominating, superior to everything and everyone deemed weak, especially females, and endowed with the right to dominate and rule over the weak and to maintain that dominance through various forms of psychological terrorism and violence (18).

She condemns such system that gives one sex the right to rule over others simply because they are born male. Patriarchy to hooks is socially and politically driven, and places men in a more superior position; giving them the latitude to dominate the world through various forms of violence and even through psychosomatic terrorism.

Masculinity in African drama finds its roots in the overpoweringly entrenched patriarchal thinking that men are superior to women, and they should emphasize their dominance by enforcing discipline (like beatings) whenever the woman 'misbehaves'. But it is clear that when women take a stand and fight for their rights and the rights of other women, these men begin to rethink their antagonistic insolences towards women. It is in such circumstances that women tend to know that "men and women are created equal" (108). This slogan is used repeatedly in Our Husband Has Gone Mad Again by Mama Rashida and Sikira, who unexpectedly gained cognisant of the injustices that society has enforced on women, and made them to pass through. In his article "Elechi Amadi's Women: Voices of Reason", George Nyamndi (2005) posits that,

The further back one goes in West African fiction as a whole... the more pronounced is society's gender bias in favour of masculinity. This trend is in keeping with the return to the mainspring of traditional culture and ultimately to its patriarchal beginnings. (80).

Many African societies show a lot of bias against the female gender when it comes to raising children. Many fathers will prefer to have sons as children, and when the child happens to be a girl, she is her mother's property.

The African perception of men in a patriarchal set up sometimes accounts for the violence in Africa. As children, boys are raised to believe that they are superior to girls: they play around while the girls cook, they are trained to do the hard jobs like splitting firewood and tapping palm wine, while girls' chores include childcare, cooking or the family, laundry, shopping, fetching water, home maintenance, and then serving men. These boys grow up with this notion that their sisters should do all the work while they give orders. They are socialized to believe that they are the men of the house, and in the absence of their father, they take the lead. As a male child grows up, they are often told that they cannot play "female" games like 'tabala' or use dolls; they should instead go for outdoor games like football, hunting birds and cane rats. These boys are socialized to know that their role is to be the protégée of their sisters and family. In any situation of pain, boys must not cry or show emotions, because men are expected to be resilient and brave. Phrases like 'men don't cry', 'be a man', 'go out there and provide for the family', and 'tough guy' are characteristic toxicmasculine expressions that are regularly used on young boys. This is what Michael Flood refers to as 'toxic masculinity': those cultural norms that are associated with harm to society and to men themselves. Toxic masculinities include traditional stereotypes of men as socially dominant, and can be considered "toxic" due in part to their promotion of violence, including domestic violence and sexual assault. The socialization of 
boys in most patriarchal societies often puts violence on a normal footing, such as in the saying "boys will be boys" with regard to antagonism and social harassment. As men, they expect their wives to do every house chore while they lazy around. Anne Tanyi Tang captures this very clearly in her play:

Eneta: Still in bed. What is so difficult in boiling rice.

Enoh: I drank a cup of tea. I was alright.

Eneta: and now, are you alright?

Enoh: There are some yams and ...

Eneta: Why didn't you cook some?

Enoh: Cook some? You must be joking. If I didn't cook when you were in Nigeria, I should start cooking now?

Eneta: Oh yeah! I can't bear it any longer. You expect me to return from work after a difficult day and cook for you? Please, let's get it straight. If you were working, I would have understood. But lying in bed twenty-four hours is what I can't tolerate. Do you realise that you are indirectly enslaving me (46)?

Patriarchal tendencies have made Enoh to be socialized to believe that the woman is a supposed to serve him. Even though he does not work, he expects his girlfriend to go to work, hussle all day, and then return to cook for him in spite of the tiredness. But because women now challenge patriarchy and masculinity, Eneta proves to Enoh that it is not only the man who can be the breadwinner, women too can be economically viable as is the case in point. She contests his maleness and tells him that she cannot be enslaved. With the words "I am done with it. I can't be the breadwinner and at the same time your slave" (46-47), Eneta ends the longstanding relationship. She makes it clear that patriarchy and toxic masculinity cannot stop her from attaining her goal of becoming an outstanding barrister.

As the boy gets older the toxicity grows. When as a men he cannot meet up with these patriarchal expectations, people start referring to him as "woman", "Mary or Susan", or "idiot". The socialization of young boys often perpetuates this violence and bullying by claiming that "boys will be boys"; alluding to men's brutality, and encouraging them to believe that it is okay to be violent and aggressive. Patriarchal tendencies may eventually pillorize men and limit the emotions which boys and men may contentedly express towards others. It is marked by economic, political, and social expectations that men seek and achieve dominance in order to become the alpha male: domineering, controlling and leading. This is seen in Our Husband Has Gone Mad Again when the half-educated Lejoka-Brown thinks too highly of himself to the point that he becomes over-domineering and even disgraces his wife in public:

Liza: Hey!

Lejoka-Brown: To your room!

Liza: What is this?

Lejoka-Brown: You heard me!

Liza: A military exercise?

Lejoka-Brown: I said go to your room, o!

Liza: Now, wait a minute

Lejika-Brown: Go! You cheap, street woman!

(Shocked, a hand clapped over her mouth in horror. Someone in the prostrate group whistles).

Lejoka-Brown: Who did that? (Aims his rifle searchingly at group)

Liza: Me? A cheap street woman? (92) 
This is verbal abuse that stems from Lejoka-Brown's low ability, but high self-esteem. He knows that his wife is supposed to be very obedient and take any orders that he gives her without questioning. And because she is 'stubborn', he uses foul words on her by addressing her as a cheap street woman.

The influence that patriarchal society has on men is shocking, and this is one of the many reasons why feminism is needed for men, not just women. Patriarchal society confines men in a box; this man box overturns male emotions by holding men up to obsolete standards propagated by toxic masculinity. Therefore, men need feminism in order to break down the defective structures of patriarchy, and to live a life that is not slowed down by toxic masculinity or the aged out traditional roles.

African women are however becoming more aware of the need to express themselves as human beings instead of living under the dictates of the man. Those hegemonic masculinity tendencies of society that oppress and dominate women into submission are now being challenged, first by women themselves who have become more exposed, by some men who now think out of the 'male box', and by society that has realized the harm that patriarchal tendencies cause. This has forced men to start negotiating more respectable forms of masculinity; and changed women's mentality of viewing her existence. The African woman is now questioning her existence and seeks to find a place in her community as a social and political being who can also contribute economically to bring her family and herself out of poverty.

\section{The Changing Perception of the African Women}

The typical African woman is one who was born, lives and experiences the African continent first hand. She is not someone raised in another continent who claims knowledge of Africa from occasional visits or what she has read. The African woman is one who masters the culture of her people, partakes of the brunt of patriarchy, and knows the plight of the woman from experience. Some writers like Lawal Amina declare that countries like Zimbabwe have characterized African women as 'jural minors', that is, women who live their entire lives under the guardianship of men: first by their fathers and brothers, and later by their husbands and/or brothers-in-law. The Supreme Court of Zimbabwe ruled that under the customary law, such women cannot inherit property even when named as the heir by the deceased (126). Other writers stress how African women had been free-thinkers and unrestrained from time immemorial, taking care of their lives and being respected by the society.

From my own experience as an African woman, and from research carried out on the African woman of some years past, women were very noticeable in their communities. They were goddess, soothsayers, queens, queen-mothers, and even deities. Queen Aminato, daughter of Bakwa Turunku, was a great Hausa warrior and princess who eventually became Queen, taking over from her mother. She ruled for over three decades in the $16^{\text {th }}$ century and left an indelible mark as a warrior and great ruler. Several other examples abound. Oyewumi Oyeronke (2003) avers that female deities and elemental powers were venerated by women and men alike (12). No one gender was more superior to the other.

As the world evolved, men became more conscious of the unlimited powers that women willed. They realized that women could do better than them if stumbling blocks were not placed along their paths. That is when patriarchy set in and tides changed. As women became too busy with child-bearing and home-keeping, and as many women were uprooted from their villages and got married in far-off villages, men took over the running of local and community affairs; and before long these men were the ones making laws, which were made to suit them, resulting in unfair social systems which favoured men more. Tides then started changing in favour of the menfolk.

Marxist Feminists believe that apart from the unfair social systems in place that give women an inferior position, the economic system, especially capitalist structures, have pushed women to the peripheries. Socialist feminists have emphasized that when class oppression is overcome, gender oppression would vanish as well, and such vision of gender oppression has gone towards specifying how gender and class work together to create distinct forms of oppression and privilege for women and men of each class.

We are saying that in spite of the disadvantaged status placed on women, the African woman has always performed very important roles in her community, and sometimes power may revolve only around these women. Some women perform the role of a native doctor and healer among many African peoples, since the basic medical care takes place within the family. It has been a truism that the woman is the doctor and 
caregiver in every family. She always knows what herbs to use in treating children for various ailments and what food to give to a convalescent person.

In recent decades, African women have become more involved in political and economic affairs. More women have joined the formal sector of the economy (especially the public sector), more girls are continuing to higher education and joining technical professions, more women can be found in the management ladder, more women are moving into professions so far dominated by men such as President of a country, medical doctors and pilots; and more women are becoming self-employed.

In his article 'Patterns of Culture and Women's Struggle for Equality in Alobwed'Epie's The Lady with a Beard" (2014), Gerard-Marie Messina writes that:

The African woman seems to always have been relegated to the background, but seizing the opportunities of the societal changes of the world, she is slowly and radically imposing herself rather than remaining a mere spectator, aiming at turning things around. The essence of her struggle is to give herself a sense of self as worthy, effectual and contributive human being (202).

Messina here opines that the African woman flows with the current. She does not let patriarchy slow her down but radically imposes herself in societal happenings. Women are now involved in politics, activism, and economic pursuit.

Notable women in politics in Africa in recent times include, but are not limited to women who have moved the world with extraordinary deeds and achievements: Ellen Eugenia Johnson Sirleaf of Liberia was the first ever female President in Africa, with a man, Joseph Boakai as her Vice President. She served as the $24^{\text {th }}$ President of Liberia from 2006 to 2018. Born on the $29^{\text {th }}$ October 1938, Sirleaf (now 81), was the first elected female head of state in Africa and also won the Nobel Peace Prize in 2011, in recognition of her efforts to bring women into the peacekeeping process. She has received numerous other awards for her leadership. In June 2016, Sirleaf was elected as the Chair of the ECOWAS, making her the first woman to hold the position since it was created. She was married to James Sirleaf and together they had four sons before their divorce. Through her sons she has ten grandchildren. There is also Joyce Banda of Malawi, Ameenah Gurib of Mauritius, and Sahle-Work Zewde, all political women who have risen to become Presidents of their respective countries.

In addition to several other female political leaders, Africa can also boast of numerous female artists, writers, and activists like Miriam Makeba (South African singer and apartheid activist), Chimamanda Ngozie Adichie (Nigerian Novelist and speaker), Bethlehem Alemu (Ethiopian entrepreneur of Sole Rebels), Wangari Muta Maathai, a renowned Kenyan social, environmental and political activist and the first African woman to win the Nobel Prize as defender of the Earth; and Cameroonian Women's Rights Activist, Aissa Doumara Ngatansou who won France's inaugural Simone Veil Prize for helping victims of rape and forced marriage. These women are a motivation to other women, and are an indication that women are not just silent followers, they are front-runners and inspirational leaders too.

In Our Husband Has Gone Mad Again, Lejoka-Brown's third wife, Lizy, is a trained medical doctor. We see her encouraging her co-wives to become more industrious even with their petite business. She teaches Mama Rashida how to be more industrious, and succeeds to ingrain in Sikira's head the fact that "men and women are created equal" (108). Her education helps her to reject men's suppression with a firm resolve. She refuses to be bullied around by her husband and makes her co-wives and other women to know that their voices matter in any squabble. In a disagreement scene with her husband, Liza refuses to be suppressed:

Liza: Well, sir, I am in no mood to be slobbered on!

(Gets up and moves away; explosion any moment now.)

Lejoka-Brown: Now listen to me, 'Lizabeth, I've been trying to welcome you ever since you ...

\section{Liza: No!}


(Whirls round, facing Lejoka-Brown)

You listen to me, Mr. Major.

(She advances, forcing Lejoka-Brown to back up defensively. They both look like awkward partners doing the tango.) ...

I've been waiting patiently ... ooh, so patiently, for you to c-o-o-1 it, so I could say something. But no. now, you listen to me, buddy and man, you listen good! (61)

In a very subtle manner, Liza shows to Lejoka Brown that a woman also has values which are to be respected. She "patiently" makes him to listen to her own point of view instead of imposing all his feelings and frustrations on her. She will not accept to be bullied, or suppressed, but in line with nego-feminist tendencies, she negotiates her way through the ensuring violence and ends up calming her husband.

Rotimi's Women have also joined the political fold and become politicians at very high level. When LejokaBrown could not lead the people well in his political party, the women wing of the party decided that no man was to lead them again. It was time for women to become the head. In the play Our Husband Has Gone Mad Again, Ola Rotimi empowers women by showing how collectively, the womenfolk can form a resilient force to overthrow men in any sphere of life. A woman's reign is equated to liberty and freedom. This is what happens when Sikira seeks to become her party's leader:

Crowd: Freedom, freedom,

Everywhere there must

Be freedom.

(Borne shoulder-high in an open sedan is someone whose beaming face looks very familiar to us: Sikira).

Sikira: (declaiming) Rise up! All women of our land! Rise up and vote for freedom, or forever be slaves!

Lejoka-Brown: Who is that crab?

Okonkwo: (Looking out through the window). Come have a peep, Major.

(Lejoka-Brown hesitates.)

Sikira: Vote ... vote for me! It is true I am a woman, but that does not matter. It does not matter, because why? Because ...

Lejoka-Brown: A woman?

(Lejoka-Brown and Liza, curious, make for the front door in time to see and hear Sikira say)

\section{Sikira: MEN AND WOMEN ARE CREATED EQUAL!}

Madam Ajanaku: No more, no less! (107-108).

It doesn't matter whether the political leader is a man or woman because men and women are created equal. The Market Women are a powerful and dynamic group which can make or mar. This shows that women are no more hand-clappers in political affairs; they are decision-makers and capable leaders.

In the conclusion to her book, The Second Sex, Simone de Beauvoir (1974) argues that the age-old conflict between the sexes no longer takes the form of women attempting to hold back man in her own prison of immanence, but rather in her own effort to emerge into the light of transcendence. She says women's situation will be transformed primarily by a change in their economic condition; but such change must also generate moral, social, cultural and psychological transformations (683). Eneta in Tanyi Tang's Eneta vs Elimo is determined to effect that change; not by holding back men, but by emerging into the limelight. She does not allow anyone to stop her dreams of becoming a lawyer, not even other women like Madam the Directress. She says:

Egbe: You are very outspoken. 
Eneta: Initially, my liberty was snatched away.

Now, I express my views uninhibited.

Thanks to the Almighty God (51).

Eneta is now empowered, and this gives her the audacity to face men and even walk out on them. Egbe, a suitor, is surprized with her boldness and sense of purpose, and wheezes with incredulity by telling her that she is very outspoken. This shows that African women's perception of subordination has become very subjective. Women have learned to assert themselves and to take charge of their lives. When women are economically empowered, gender-based violence also reduces.

\section{Female Chauvinism}

This refers to female domineering attitude over men. It is a new stereotype dogma that believes that women should lead and the men should follow. It's the direct opposite of male chauvinism, dominance or matriarchal roles. In his book Masculinities, Robert Connell (1995) stands against the notion of "true masculinity," accentuating that masculinity (like femininity) is not a coherent object, but part of a bigger structure. This therefore supports the fact that being born a woman does not restrict the woman from performing societal roles attributed to men, and that includes leading the men.

In Ola Rotimi's Our Husband Has Gone Mad Again, the polygamist, Lejoka-Brown, is forced to marry Mama Rashida, his late brother's wife. This Marriage is contracted in line with the customs and tradition of the people which requires a brother in the family (blood brother, cousin or even nephew) to marry his brother's widow as a way of keeping the family together and someone taking care of the late brother's wife and children. Such marriage is also meant to ensure continuality, and make sure the widow does not minglemangle 'bad blood' (illegitimate children) into the family. Levirate marriages however, are habitually breeding grounds for violence in a marriage because the widow is often seen as an intruder in her new union, or an opportunist looking for someone to raise her children. Sometimes she is ignored by her husband and his other wives; at other times the woman is seen as the epitome of all the problems faced by the household. Mama Rashida however has become very bold because of the influence of Liza. The one time obedient wife has become audacious enough to try to control her husband. The exchange below explains her selfassurance:

Mama Rashida: what's the matter, my Lord?

Lejoka-Brown: with my toes?

Mama Rashida: No, with Liza

Lejoka-Brown: Oh she says she's going home

Mama Rashida: Hunh? And what is my Lord doing to stop her?

Lejoka-Brown: Bumping my toes against a chair.

Mama Rachida: Is that so? Very well then, perhaps you'd better start bumping into another woman who will take care of the house after Liza leaves, because if you think I will leave my big new trade and stay home all day, you mistake! (She exits in a huff, Lejoka-Brown gaping after her with horrified disbelief) (100).

The fact that Lejoka-Brown gaps after her shows how shocked he is with Mama Rashida's new attitude. He cannot believe that his wife can talk back to him in that manner, but this simply shows female chauvinism and the woman's readiness to lead the man if given the opportunity. Even after being married to LejokaBrown for four years following her husband's death, Mama Rashida is considered an old woman. She has been a stay-at-home wife, doing everything to run her home and remaining consciously submissive to her husband as expected from every African wife. But the educated Liza has created some awareness in the women, making them know that "men and women are created equal" (108). 


\section{Conclusion}

The perspective of viewing women as the victims of patriarchy and male violence is gradually losing centrestage in gender discourse in recent times because the prescribed opinion of the African woman as silent and relegated to the margins is changing as well. Most women have challenged patriarchal norms, and have moved from the peripheral boundaries of society, home affairs as well as politics to occupy the centre. The new African woman nowadays calls the shots, they own houses, run businesses, are educated and challenge the status quo at all times. African female writers like Mariama Ba, Chimamanda Adichie, Tsitsi Dangarembga, and Buchi Emecheta are very vocal in their works about the injustices society has put women through. They speak as the voice of the voiceless for women whose rights and dignity have been trampled on by biased patriarchal systems. However, I strongly hold that as necessary as it is to keep women empowered, it is equally vital that men's rights should not be trampled on in this process as this gives rise to another situation of gender imbalance.

Ogaga Okuyade (2009) affirms that the creative art for the African writer is not just an art form that seeks to entertain the audience, it functions beyond that, it is more of a social document geared towards the reconstruction of the socio-political configuration of the African people (246). Helen Chukwuma (2003) on her part contends that the novelist does more than simple story telling in a beautiful manner: "He arouses in the reader a true sense of himself, evoking his past and linking it to the present" (VI). It is in this light that this article has drawn attention to the contemporary issue of women and patriarchal oppression; and has raised evidence to the fact that today's African women are challenging masculinity and breaking grounds in all spheres of life. African women are empowered.

It is Ama Ata Aidoo (1998) in "The African Woman Today" who challenges men and tells them to work alongside women because they have held power long enough and women are now ready to emerge:

In the meantime, if, like men around the world, African men habor any phobias about women moving into leadership positions, them they had better get rid of them quickly. After all, men have monopolised leadership positions in Africa over the last five hundred years, and still overwhelmingly do. ... It is high time African women moved unto center stage, with or without anyone's encouragement. Because in our hands lie, perhaps, the last possible hope for ourselves, and for everyone else on the continent (48).

Aidoo encourages women to move to the center stage and take responsibilities and leadership roles because no one will give them in a platter of goal. And this is exactly what some female characters in Our Husband Has Gone Mad Again and Eneta vs Elimo are doing. These characters have shunned patriarchy and changed their mind-sets about being subordinated and left at the periphery. The article has debunked the notion of women as being unempowered, and shown them as applying the nego-feminist tenets of cooperating with men to negotiate their way through patriarchy as a means of achieving their goals of empowerment and strength of mind to effect socio-political change in their communities.

\section{References}

\section{A. Primary Texts}

[1.] Rotimi, Ola (1999). Our Husband Has Gone Mad Again. Ibadan: Oxford University Press.

[2.] Tanyi-Tang, Anne (2007). Eneta vs Elimo. Yaounde: Edition CLE.

\section{B. Secondary Texts}

[3.] Aidoo, Ama Ata (1998). "The African Woman Today". Sisterhood, Feminisms and Power: From Africa to the Diaspora. Edited by Nnaemeka Obioma. Trenton, NJ: Africa World Press, pp. 39-50.

[4.] Bell hooks (2000). Feminism is for Everybody: Passionate Politics. Cambridge: South End Press.

[5.] Chukwuma, Helen (2003). Accents in the African Novel. Lagos: Pearl Publishers.

[6.] Connell, W. Raewyn (1987). Gender and Power. Cambridge: Polity Press.

[7.] Connell, Robert (1995). Masculinities. Cambridge: Polity Press.

[8.] De Beauvoir, Simone (1974). The Second Sex. New York : Vintage Books.

[9.] Messina, Gerard-Marie (2014). "Patterns of Culture and Women's Struggle for Equity in Alobwed'Epie's The Lady with a Beard". Perspectives on Cameroonian Art, Archaelogy and 
Culture: Papers in Honour of Professor Bole Butake. Edited by John Nkemngong Nkengasong. Yaounde: Edition Cle, pp. 199-209.

[10.] Nnaemeka, Obioma (2005). "Nego-Feminism: Theorizing, Practicing, and Pruning Africa's Way". Signs Journal of Women in Culture and Society. Vol. 29, No. 2, pp. 357-385.

[11.] ................... (2005) "Bringing African Women into the Classroom: Rethinking Pedagogy and Epistemology." In Oyewumi Oyeronke (Ed.) African Gender Studies: A Reader. New York: Palgrave Macmillan. Pp 51-65.

[12.] Norris, Christopher (2002). Deconstruction: Theory and Practice. New York: Taylor \& Francis Group.

[13.] Nyamndi, George (2005). "Elechi Amadi's Women: Voices of Reason". Gender, Literature and Religion in Africa. CODESRIA. Pp 79-94

[14.] Oyewumi, Oyeronke (2003). "Ties that (Un)Bind: Feminism, Sisterhood and Other Foreign Relations". African Women and Feminism: Reflections on the Politics of Sisterhood. Trenton, NJ: African World Press, pp. 1-24.

[15.] Okuyade, Ogaga (2009). "Changing Borders and Creating Voices: Silence as Character in Chimamanda Adichie's Purple Hibiscus". The Journal of Pan African Studies. Vol. 2, No. 9, March 2009, pp. 245-259.

\section{Biography}

Taku Catherine is a PhD Research Fellow at the University of Buea. She holds a Master's Degree in African Literature and a Post-Graduate Diploma in Women and Gender Studies. She is a Cameroonian Poet, Writer of Short Stories and a Folklorist. Her published works include Tears of the Innocent (a collection of 40 poems), Grandma's Legacy (a collection of 15 short stories), and Folktales From the Forestland. She has also published articles online and in International Journals. Her areas of interest include ecological studies, gender and feminist dialectics. 